Journal of Agriculture and Natural Resources (2019) 2(1): 14-35

ISSN: 2661-6270 (Print), ISSN: 2661-6289 (Online)

DOI: https://doi.org/10.3126/janr.v2i1.26012

Research Article

\title{
On-farm Conservation Approaches for Agricultural Biodiversity in Nepal
}

\author{
Bal Krishna Joshi ${ }^{1 *}$ and Deepak Upadhya ${ }^{2}$ \\ ${ }^{1}$ Genebank, Nepal Agricultural Research Council, Khumaltar, Lalitpur, Nepal \\ * Corresponding author Email: joshibalak@yahoo.com \\ ORCID: https://orcid.org/0000-0002-7848-5824 \\ ${ }^{2}$ World Wildlife Fund (WWF), Kathmandu; @: deepak.upadhya@wwfnepal.org
}

Received: June 15; Accepted: August 28; Published: October 25, 2019

(C) Copyright: Joshi and Upadhya (2019).

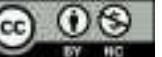

This work is licensed under a Creative Commons Attribution-Non Commercial 4.0 International License.

\begin{abstract}
Agricultural biodiversity is the basis for agricultural research and development. This paper is based on the survey across the country along with the field implementation and action research on different conservation approaches over the years and locations. Management of agricultural biodiversity is being initiated in Nepal through ex-situ, on-farm, in-situ and breeding strategies by National Agriculture Genetic Resources Center (National Genebank) from 2010. National Genebank has implemented on-farm conservation across the country. Different approaches are community seed bank, community field genebank, household seed bank, household field genebank, village level field genebank and school field genebank. In addition to these, landrace enhancement program and recognition of agro-biodiversity rich farmers have also contributed on conserving APGRs. Identification of agro-biodiversity rich farmers have been initiated in collaboration with different governmental and non-governmental organizations across the country. Strong network among these farmers is supposed to establish for effectively managing APGRs on-farm. Agro-biodiversity conserved by such farmers is called household genebank, which consist of seed storage (household seed bank) and household field genebank. There are more than $100 \mathrm{CSBs}$ in the country and some of them are conserving local genetic resources. Eight community field genebanks have been functionalized for conserving recalcitrant seeds and vegetatively propagated crop species. Village level field genebank has been established by NGO in Makwanpur district to conserve banana and taro. In this approach, different households grow different landraces, maintaining maximum diversity within a village. In some areas, school field genebank has been established by growing local APGRs in school areas. This helps to conserve APGRs, educate the students, earn the income and make environment beautiful. Genebank also encourages farmers to reintroduce the landraces from the National Genebank. Accessioning these APGRs and training to farmers and farming communities are necessary to effectively and efficiently conserving and utilizing APGRs on-farm.
\end{abstract}

Keywords: APGR, community, conservation approaches, field genebank, genebank, on-farm conservation

Correct citation: Joshi, B. K., \& Upadhya, D. (2019). On-farm conservation approaches for agricultural biodiversity in Nepal. Journal of Agriculture and Natural Resources, 2(1), 14-35. DOI: https://doi.org/10.3126/janr.v2i1.26012 
Journal of Agriculture and Natural Resources (2019) 2(1): 14-35

ISSN: 2661-6270 (Print), ISSN: 2661-6289 (Online)

DOI: https://doi.org/10.3126/janr.v2i1.26012

\section{INTRODUCTION}

Nepal is largely an agrarian country where crops cultivation ranges from $60 \mathrm{~m}$ to $4,700 \mathrm{~m}$ altitude (Joshi et al., 2017a). The nation holds 484 cultivated indigenous crop species with an estimated 30,000 native landraces. Study shows that even in a small village of Nepal there is diversity of local varieties, among which many landraces have capacity to cope with different biotic and abiotic stresses. Such crops diversity are being maintained by farmers at farming areas by planting the seed, selecting the harvest or exchanging it with other farmers, and replanting. Unfortunately, due to modern and hybrid varieties and other factors, about $50 \%$ of crop diversity has been lost in the past (Joshi et al., 2017a). To conserve local crop intraspecific diversity, on-farm conservation has been widely adopted in Nepal since 1995.

Local crop diversity contributes a wide range of goods and services to food, fiber, fuel, health, and livelihood security through resisting, absorbing and recovering from the various effects of biotic and abiotic stresses (Altieri, 1999; Jarvis et al., 2007; Mijatovic et al., 2013; Vanek and Drinkwater, 2013; Upadhya et al., 2016). Field crop diversity is fundamental to agricultural growth. It enables agricultural communities to develop higher yielding, more productive varieties that have the improved quality characteristics required by farmers and desired by consumers (Shrestha et al., 2019). The value of agricultural biodiversity is immense to meet the day to day needs and long-term sustainability at food and agricultural sector across the world. Genetic diversity is the basis for scientific research to derive different varieties, techniques and methods suitable for different agroecology.

Farmers have been doing conservation of agricultural biodiversity for centuries. Similarly, the issue and agenda of agricultural biodiversity has got prime concern at scientific community with the international agreements: Convention of Biological Diversity (CBD), International Treaty on Plant Genetic Resources for Food and Agriculture (ITPGRFA), Nagoya Protocol and similar other agreements over the last decade. Despite the importance of agricultural diversity to create entire panoply of divesity, it has been actively managed and taken care only by the farming communities in the past in Nepal. Like at the international community, systematic attempt to assess what approaches are being adopted, and what other can be added for the conservation and management of agricultural biodiversity in Nepal has been initiated only after the establishement of National Agriculture Genetic Resources Center (NAGRC, National Genebank) in 2010. NAGRC has been adopting four strategies, namely on-farm, ex-situ, in-situ and breeding and have developed a number of approaches and methods for conservation and management of total agrobiodiversity in the country (Joshi et al., 2017a). Red zoning and red listing systems are in practice to prioritize the agricultueral plant genetic resources (APGRs) for conservation and use. Government of Nepal has also adopted on-farm conservation strategy and mainstreamed it in a number of policy and strategy documents (e.g. Seed act (First amendment): 2008.1.24, Seed Act 2045 (1988) and the 2008 amendment, Seed Regulations 1997 and amendment 2013, Plant Variety Protection and Farmers' Rights Bill, Agro-biodiversity Policy 2007 and the 2014 amendment, National Agriculture Policy 2004, Agriculture Development Strategy 2014, National Biodiversity Strategy and Action Plan 2014-2020, IMISAP, Zero hunger, Constitutions). Though, different approaches have been adopted to conserve the agricultural biodivesity yet no systematic attempt has been made to compile those information which can be assessed by the national and international communities. Present attempt is therefore to pacakage those 
Journal of Agriculture and Natural Resources (2019) 2(1): 14-35

ISSN: 2661-6270 (Print), ISSN: 2661-6289 (Online)

DOI: https://doi.org/10.3126/janr.v2i1.26012

information in one portol so that it can be easily available and accessible across different levels and make the conservation effort more efficient and effective.

\section{METHODOLOGY}

\section{Literature review}

On-farm conservation has been adopted as a separate conservation strategy in Nepal since 1995. A number of publications are available under on-farm conservation program, and this study reviewed these and provided a synthesis of published annual report, booklet, proceedings, journal and reports of NARC, LIBIRD, MoALD and Bioversity International on on-farm conservation approaches.

\section{Field survey}

Since the field survey are a major part of this study, after discussing with key organizations and experts, potential sites were identified. Based on the agro-climatic variation and success cases, study team identified and visited 70 sites for field survey from 2014 to 2017, and collected in-depth data and information on list of activities and crops, farmers' reaction, name list of organizations, impact on farming communities and agro-biodiversity, etc. Details on some of many field surveys are presented in Table 1.

Table 1. Details of field survey

\begin{tabular}{|c|c|c|c|}
\hline Date of survey & Location & $\begin{array}{l}\text { Number of } \\
\text { participants }\end{array}$ & Survey theme \\
\hline 17 May 2014 & Ilam & 15 & $\begin{array}{l}\text { Household genebank, community } \\
\text { biodiversity management }\end{array}$ \\
\hline 11 April 2015 & Talium-2, Jumla & 13 & $\begin{array}{l}\text { Landraces diversity, community seed } \\
\text { bank and household genebank }\end{array}$ \\
\hline 4 December 2015 & Bhadaure, Kaski & 25 & Varietal diversity \\
\hline January 2016 & Hariyarpur-06, Kanchanpur & 20 & $\begin{array}{l}\text { On-farm varietal diversity and its } \\
\text { importance }\end{array}$ \\
\hline 12 February 2016 & Begnas, Kaski & 2 & Household genebank \\
\hline 28 March 2016 & Kachorwa, Bara & 15 & $\begin{array}{l}\text { Community seed bank, field genebank, } \\
\text { landraces and its importance and } \\
\text { varietal diversity }\end{array}$ \\
\hline 12-13 February 2017 & Chhatiwan, Makwanpur & 17 & $\begin{array}{l}\text { On-farm conservation of } \\
\text { agrobiodiversity }\end{array}$ \\
\hline
\end{tabular}

\section{Interview}

Key informant survey (KIS) with 25 experts, 15 focus group discussion (FGD) and 150 farmers were consulted for information collection and validations. Interviews were either face to face interaction, email or telephone conservations. We also collected information with the participants of three national workshops.

\section{Field implementation and action research}

NAGRC, LI-BIRD and Bioversity International have jointly implemented on-farm conservation related activities in different sites across the country. Some noticeable sites are Kachorwa, Bara; Jugu, Dolakha, Ghanpokhara, Lamjung; Haku, Jumla; Talium, Jumla; 
Journal of Agriculture and Natural Resources (2019) 2(1): 14-35

ISSN: 2661-6270 (Print), ISSN: 2661-6289 (Online)

DOI: https://doi.org/10.3126/janr.v2i1.26012

Chhipra, Humla; Begnas, Kaski; Rainas, Lamjung; Dalchoki, Lalitpur; Gadaria, Kailali; Simaria, Sunsari; Purkot, Tanahu; etc. Different approaches have been adopted e.g. some activities were directly implemented in the fields; some were implemented through farmers groups and some through local NGOs. Activities implemented in these sites along with their status are reported here. One of the major impacts of some of activities is that many other governmental as well as non-governmental organizations have mainstreamed these activities. This paper therefore will further be helpful to expand these activities at wider scale by different organizations.

\section{RESULTS AND DISCUSSION}

\section{Conservation ladder and on-farm conservation methods}

A concept of conservation ladder is promoted in Nepal, with three steps, local, national and international levels (Figure 1). At local level, there are three main strategies, namely on-farm conservation, in-situ conservation and breeding (Figure 2). Within on-farm conservation, about 15 different methods have been developed and most of them are widely applied in Nepal. Among them, community seed bank and community field genebank are very common and many communities have established for management of local crop diversity.

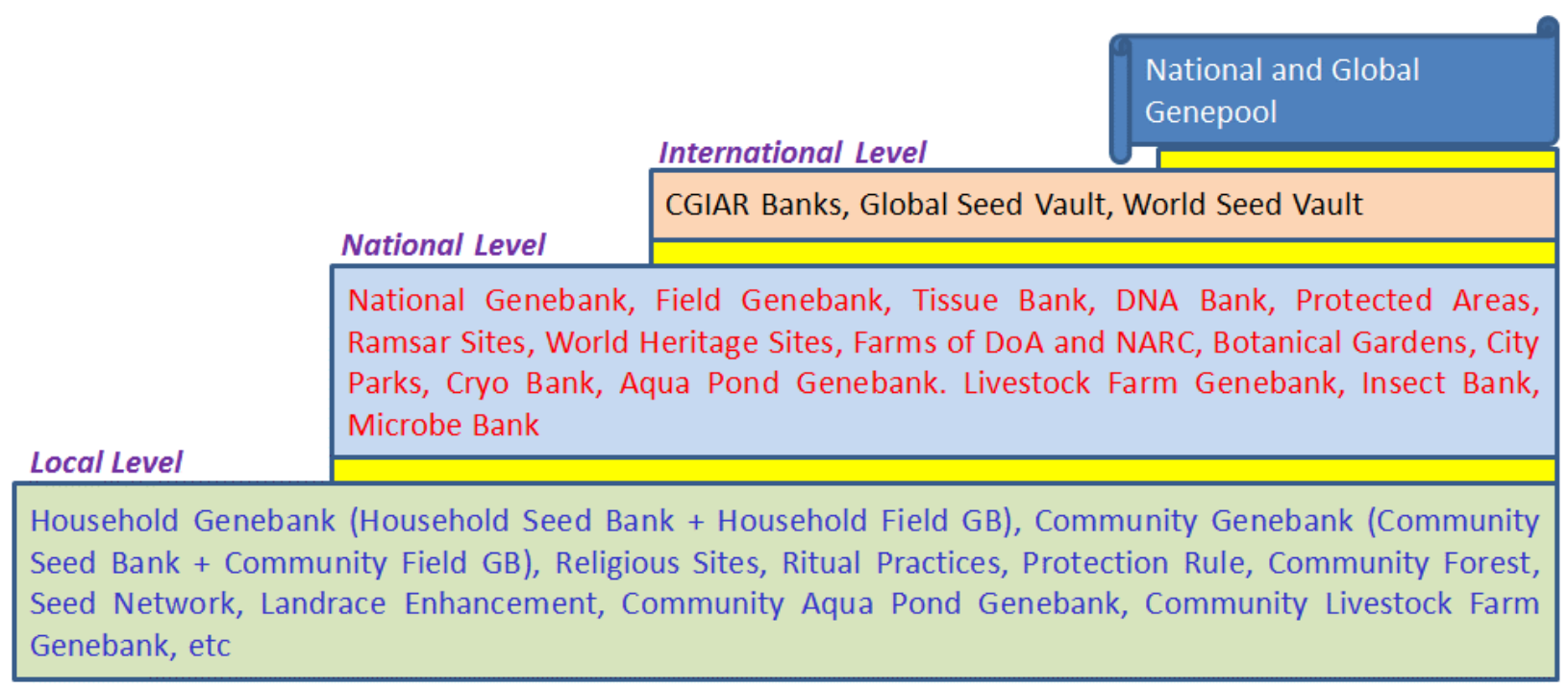

Figure 1. Different approaches and methods for conservation of agrobiodiversity at local, national and global levels (Joshi et al., 2017a). Temple garden and office garden are additional methods in all these levels. 
Journal of Agriculture and Natural Resources (2019) 2(1): 14-35

ISSN: 2661-6270 (Print), ISSN: 2661-6289 (Online)

DOI: https://doi.org/10.3126/janr.v2i1.26012

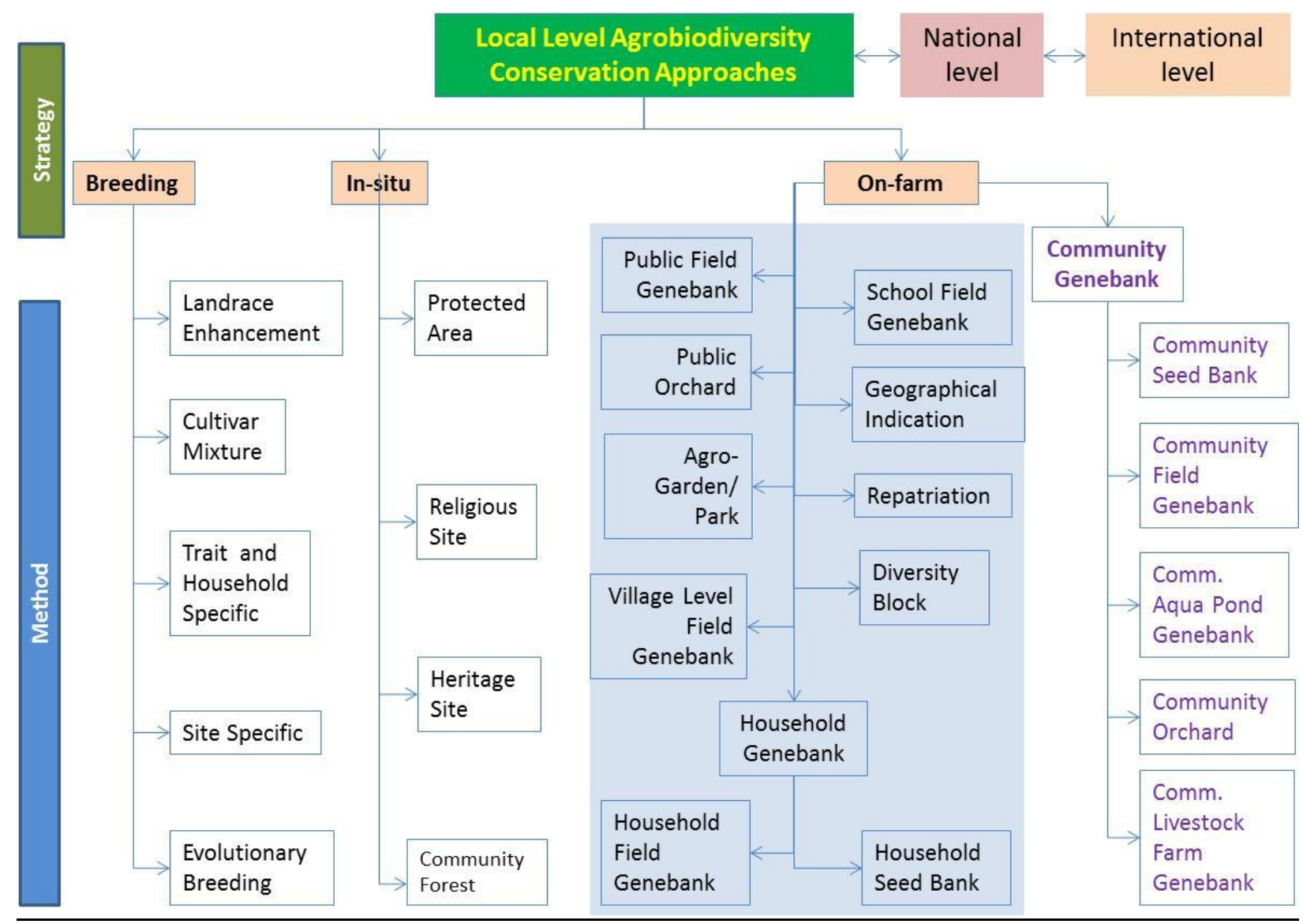

Figure 2. Agrobiodiversity conservation approaches and methods at local level adopted in Nepal

\section{Understanding on-farm conservation}

On-farm conservation is a strategy that support for continue cultivation of local crop diversity by farmers over the time. Some agriculturists include on-farm conservation under the in-situ, but in Nepal it is treated as a separate strategy and difference among ex-situ, in-situ and onfarm are described in Table 2.

Table 2. Comparative analysis of three conservation strategies

\begin{tabular}{lllll}
\hline SN & Feature & Ex-situ & In-situ & On-farm \\
\hline $\begin{array}{l}\text { 1. } \\
\text { collections }\end{array}$ & $\begin{array}{l}\text { Other than storage } \\
\text { site }\end{array}$ & $\begin{array}{l}\text { Same place (at least one } \\
\text { allele should be evolved) }\end{array}$ & $\begin{array}{l}\text { Other than cultivation site. Traits/ } \\
\text { landraces not evolved but } \\
\text { continue cultivation of landraces } \\
\text { in farm }\end{array}$ \\
\hline 2. & $\begin{array}{l}\text { Site for plant life } \\
\text { cycle }\end{array}$ & $\begin{array}{l}\text { Mostly kept in } \\
\text { dormant condition }\end{array}$ & $\begin{array}{l}\text { Whole (active and } \\
\text { dormant) period in same } \\
\text { place }\end{array}$ & $\begin{array}{l}\text { Active period in field and } \\
\text { dormant period in nearby field ie } \\
\text { farm store (household) }\end{array}$ \\
\hline 3. & Approach & $\begin{array}{l}\text { Static storage, } \\
\text { conservation } \\
\text { through } \\
\text { management }\end{array}$ & $\begin{array}{l}\text { Dynamic, nature } \\
\text { protection }\end{array}$ & $\begin{array}{l}\text { Continue cultivation of landraces, } \\
\text { conservation through continue } \\
\text { cultivation and use }\end{array}$ \\
\hline 4. & $\begin{array}{l}\text { Evolution process, } \\
\text { creation of }\end{array}$ & Stop (arrested) & Continue & $\begin{array}{l}\text { Continue. Completely adopted } \\
\text { stage in a farm (more than 30 }\end{array}$ \\
\hline
\end{tabular}


Journal of Agriculture and Natural Resources (2019) 2(1): 14-35

ISSN: 2661-6270 (Print), ISSN: 2661-6289 (Online)

DOI: https://doi.org/10.3126/janr.v2i1.26012

\begin{tabular}{lllll}
\hline SN & Feature & Ex-situ & In-situ & On-farm \\
\cline { 1 - 4 } & variation & & & $\begin{array}{l}\text { years), relatively more diversity } \\
\text { within landrace }\end{array}$ \\
\hline 5. & Storage condition & Controlled & Natural & Normal and room temperature \\
\hline 6. & Seed container & Need air tight & No need of container & Normal container \\
\hline 7. & Seed moisture & Lowered to 3-7\% & Natural & Sun dried \\
\hline 8. & Regeneration & $\begin{array}{l}\text { At 5-10 years } \\
\text { interval }\end{array}$ & Naturally & Annually or seasonally \\
\hline 9. & Example & $\begin{array}{l}\text { National Genebank, } \\
\text { Field Genebank, } \\
\text { Botanical Garden }\end{array}$ & $\begin{array}{l}\text { National Park, Protected } \\
\text { Area, Cultivation farm for } \\
\text { crops where at least one } \\
\text { trait evolved }\end{array}$ & $\begin{array}{l}\text { Household Genebank, } \\
\text { Community genebank, } \\
\text { Cultivation farm }\end{array}$ \\
\hline
\end{tabular}

Source: Joshi 2017

\section{Key players and their contributions on on-farm conservation}

More than 14 organizations work on on-farm conservation in Nepal and spread across all 77 districts through direct, partnership and joint presence. On-farm conservation approaches and supporting program of these organizations are given in Table 3. A number of different approaches have been developed and implemented along with different supporting programs. Among these organizations, LI-BIRD and NARC are the exemplary organizations on conservation and utilization of agrobiodiversity following on-farm conservation strategy. Almost $30 \%$ of local crop diversity is being conserved under different methods of on-farm strategy in the country.

Table 3. Organizations involved in on-farm conservation and approaches adopted

\begin{tabular}{|c|c|c|c|c|c|}
\hline $\begin{array}{l}\mathbf{S} \\
\mathbf{N}\end{array}$ & $\begin{array}{l}\text { Organizati } \\
\text { on }\end{array}$ & Address & $\begin{array}{l}\text { On-farm } \\
\text { conservation } \\
\text { approaches }\end{array}$ & Working areas & Supporting program \\
\hline 1. & LI-BIRD & $\begin{array}{l}\text { Gairapatan, } \\
\text { Pokhara }\end{array}$ & $\begin{array}{l}\text { Community seed } \\
\text { bank, field } \\
\text { genebank, } \\
\text { participatory plant } \\
\text { breeding, } \\
\text { participatory varietal } \\
\text { selection, home } \\
\text { garden, diversity } \\
\text { block, diversity field } \\
\text { school, mother and } \\
\text { baby trial, etc. }\end{array}$ & $\begin{array}{l}\text { Jugu and Namdu, Dolkha; } \\
\text { Purkot, Tanahun; Agyouli, } \\
\text { Nawalparasi; Tailium and } \\
\text { Haku, Jumla; Chhipra, Saya, } \\
\text { Gothi, Melchham, Simikot } \\
\text { and Darma, Humla; } \\
\text { Kachorwa, Bara; Rampur, } \\
\text { Dang }\end{array}$ & $\begin{array}{l}\text { Identifying promising } \\
\text { landraces and registration; } \\
\text { Establish, promote and } \\
\text { strengthen community } \\
\text { seeds banks and } \\
\text { community-based seed } \\
\text { production; Establish and } \\
\text { strengthen farmer-to- } \\
\text { farmer seed system; } \\
\text { Research on neglected and } \\
\text { underutilized crops, value } \\
\text { chain; Revolving fund and } \\
\text { seed money }\end{array}$ \\
\hline 2. & $\begin{array}{l}\text { Parivartan } \\
\text { Nepal }\end{array}$ & $\begin{array}{l}\text { Sano } \\
\text { Pokhara, } \\
\text { Hetauda, } \\
\text { Makawanpu } \\
\text { r }\end{array}$ & $\begin{array}{l}\text { Riverbank } \\
\text { conservation, field } \\
\text { genebank, CSB, } \\
\text { school field } \\
\text { genebank, landraces } \\
\text { registration, organic } \\
\text { farming }\end{array}$ & $\begin{array}{l}\text { Phaparbari, Thulosudha and } \\
\text { Chhatiwan, Makwanpur; } \\
\text { Ranibas, Sindhuli; } \\
\text { Pattharkot, Sarlahi }\end{array}$ & $\begin{array}{l}\text { Fodder \& forage seeds } \\
\text { sowing at riverbank; } \\
\text { Identify and register } \\
\text { unique landraces; } \\
\text { Seasonal organic } \\
\text { vegetable farming; } \\
\text { Training \& support }\end{array}$ \\
\hline 3 . & $\begin{array}{l}\text { Dalit } \\
\text { Welfare } \\
\text { Organizatio } \\
\text { n }\end{array}$ & $\begin{array}{l}\text { Kohalpur, } \\
\text { Banke }\end{array}$ & $\begin{array}{l}\text { Home garden, } \\
\text { diversity kit, bio- } \\
\text { pesticides } \\
\text { preparation, } \\
\text { custodian farmers, }\end{array}$ & $\begin{array}{l}\text { Kachanapur, Binauna and } \\
\text { Baijapur, Banke }\end{array}$ & $\begin{array}{l}\text { Integrated pest } \\
\text { management; Mulch } \\
\text { farming with low cost drip } \\
\text { irrigation technology; } \\
\text { Shed improvement for }\end{array}$ \\
\hline
\end{tabular}


Journal of Agriculture and Natural Resources (2019) 2(1): 14-35

ISSN: 2661-6270 (Print), ISSN: 2661-6289 (Online)

DOI: https://doi.org/10.3126/janr.v2i1.26012

\begin{tabular}{|c|c|c|c|c|c|}
\hline $\begin{array}{l}\mathbf{S} \\
\mathbf{N}\end{array}$ & $\begin{array}{l}\text { Organizati } \\
\text { on }\end{array}$ & Address & $\begin{array}{l}\text { On-farm } \\
\text { conservation } \\
\text { approaches }\end{array}$ & Working areas & Supporting program \\
\hline & & & organic farming & & $\begin{array}{l}\text { urine collection for bio } \\
\text { pesticides }\end{array}$ \\
\hline 4. & $\begin{array}{l}\text { SHIP } \\
\text { Nepal }\end{array}$ & $\begin{array}{l}\text { Simikot, } \\
\text { Humla }\end{array}$ & $\begin{array}{l}\text { Community based } \\
\text { seed production, } \\
\text { participatory variety } \\
\text { selection, bio- } \\
\text { pesticide } \\
\text { preparation, home } \\
\text { garden, organic } \\
\text { farming }\end{array}$ & $\begin{array}{l}\text { Kharpunath, Lali, Raya and } \\
\text { Sarkideu, Humla }\end{array}$ & $\begin{array}{l}\text { Diversity kit distribution, } \\
\text { Improved FYM and } \\
\text { proper use of bio-mass } \\
\text { from farm land }\end{array}$ \\
\hline 5. & Oxfam & $\begin{array}{l}\text { Jawalakhel, } \\
\text { Lalitpur }\end{array}$ & $\begin{array}{l}\text { Community seed } \\
\text { entrepreneurs } \\
\text { (transmuted CSB), } \\
\text { IPM }\end{array}$ & Across the country & $\begin{array}{l}\text { Awareness raising of } \\
\text { farmers and fisher folk } \\
\text { regarding existing } \\
\text { legislative and } \\
\text { institutional arrangements } \\
\text { concerning food security } \\
\text { and nutrition }\end{array}$ \\
\hline 6. & ActionAid & $\begin{array}{l}\text { Lazimpat, } \\
\text { Kathmandu }\end{array}$ & $\begin{array}{l}\text { CSB, sustainable } \\
\text { agriculture }\end{array}$ & Across the country & $\begin{array}{l}\text { Soil conservation, gender } \\
\text { equity, agrobiodiversity } \\
\text { preservation, processing } \\
\text { and marketing, farmer } \\
\text { groups }\end{array}$ \\
\hline 7. & CDD & $\begin{array}{l}\text { Hariharbha } \\
\text { wan, } \\
\text { Lalitpur }\end{array}$ & $\begin{array}{l}\text { CSB, home garden, } \\
\text { minikit distribution, } \\
\text { integrated crop and } \\
\text { water management } \\
\text { program, integrated } \\
\text { pest management }\end{array}$ & Across Nepal & $\begin{array}{l}\text { Facilitate Ministry of } \\
\text { Agriculture for policy } \\
\text { formulation; policy } \\
\text { implementation; subsidize } \\
\text { seed production, organic } \\
\text { farming, etc. }\end{array}$ \\
\hline 8. & ANSAB & $\begin{array}{l}\text { Bhimsen } \\
\text { Gola } \\
\text { Marga, } \\
\text { Kathmandu }\end{array}$ & $\begin{array}{l}\text { Organic agriculture, } \\
\text { In-situ biodiversity } \\
\text { conservation } \\
\text { through linking } \\
\text { conservation to } \\
\text { business and local } \\
\text { communities }\end{array}$ & Across the country & $\begin{array}{l}\text { Value chain study, market } \\
\text { study, providing } \\
\text { information on market } \\
\text { prices }\end{array}$ \\
\hline 9. & $\begin{array}{l}\text { Tribhuvan } \\
\text { University }\end{array}$ & $\begin{array}{l}\text { Kritipur, } \\
\text { Kathmandu }\end{array}$ & $\begin{array}{l}\text { Integrating agro- } \\
\text { biodiversity in } \\
\text { Natural History } \\
\text { Museum and } \\
\text { curriculum }\end{array}$ & $\begin{array}{l}\text { Centrally located but } \\
\text { collects genetic resources } \\
\text { from the different parts of } \\
\text { country }\end{array}$ & $\begin{array}{l}\text { Collection of seed } \\
\text { samples, prepare visitor } \\
\text { guidebook of the APGRs, } \\
\text { Capacity building }\end{array}$ \\
\hline 10. & $\begin{array}{l}\text { SAHAS- } \\
\text { Nepal }\end{array}$ & $\begin{array}{l}\text { Lalitpur, } \\
\text { Nepal }\end{array}$ & $\begin{array}{l}\text { Home garden, } \\
\text { organic farming, } \\
\text { botanical pesticides } \\
\text { preparation }\end{array}$ & $\begin{array}{l}\text { Bajura, Mugu, Kalikot, } \\
\text { Lalitpur, Okhaldhunga, } \\
\text { Udaypur, Dhading, } \\
\text { Tanahun, Gorkha, Rasuwa, } \\
\text { Dailekh, Rautahat, } \\
\text { Makwanpur, Sindhuli, } \\
\text { Siraha, Dhanusa, Mahotari }\end{array}$ & $\begin{array}{l}\text { Fruit sapling distribution, } \\
\text { Apple trees pruning, } \\
\text { Production and promotion } \\
\text { of neglected crops seed, } \\
\text { Diverse varieties seed } \\
\text { distribution, Registration } \\
\text { of local varieties }\end{array}$ \\
\hline 11. & $\begin{array}{l}\text { FORWAR } \\
\text { D Nepal }\end{array}$ & $\begin{array}{l}\text { Bharatpur, } \\
\text { Chhetrapur, } \\
\text { Chitwan }\end{array}$ & $\begin{array}{l}\text { Riverbed farming, } \\
\text { Participatory variety } \\
\text { selection, } \\
\text { Community Seed } \\
\text { Bank, IRD, home } \\
\text { gardening, organic }\end{array}$ & $\begin{array}{l}\text { Banke, Tanahun, } \\
\text { Nawalparasi, Chitwan, } \\
\text { Makwanpur, Bara, Rautahat, } \\
\text { Sarlahi, Sindhuli, Mahotari, } \\
\text { Siraha, Saptari, Sunsari, } \\
\text { Morang, Jhapa }\end{array}$ & $\begin{array}{l}\text { Integrated crop } \\
\text { management, Integrated } \\
\text { pest management, Variety } \\
\text { registration and release, } \\
\text { climate smart agriculture, } \\
\text { value chain development }\end{array}$ \\
\hline
\end{tabular}


Journal of Agriculture and Natural Resources (2019) 2(1): 14-35

ISSN: 2661-6270 (Print), ISSN: 2661-6289 (Online)

DOI: https://doi.org/10.3126/janr.v2i1.26012

\begin{tabular}{|c|c|c|c|c|c|}
\hline $\begin{array}{l}\mathbf{S} \\
\mathbf{N}\end{array}$ & $\begin{array}{l}\text { Organizati } \\
\text { on }\end{array}$ & Address & $\begin{array}{l}\text { On-farm } \\
\text { conservation } \\
\text { approaches }\end{array}$ & Working areas & Supporting program \\
\hline 12. & ICIMOD & $\begin{array}{l}\text { Khumaltar, } \\
\text { Lalitpur }\end{array}$ & $\begin{array}{l}\text { farming and on-farm } \\
\text { trial } \\
\text { Knowledge park, } \\
\text { Local crop diversity } \\
\text { fair }\end{array}$ & Hindu-Kush Himalaya & $\begin{array}{l}\text { Shifting cultivation, } \\
\text { integrated farming, } \\
\text { training }\end{array}$ \\
\hline 13. & $\begin{array}{l}\text { ECOSCEN } \\
\text { TER }\end{array}$ & $\begin{array}{l}\text { Narayangat } \\
\text { h, Chitwan }\end{array}$ & $\begin{array}{l}\text { IPM, organic } \\
\text { agriculture, support } \\
\text { to establish seed } \\
\text { bank, strengthening } \\
\text { market of organic } \\
\text { products }\end{array}$ & Western Nepal & $\begin{array}{l}\text { Training, visit, seed } \\
\text { money }\end{array}$ \\
\hline 14. & NARC & $\begin{array}{l}\text { Khumaltar, } \\
\text { Lalitpur }\end{array}$ & $\begin{array}{l}\text { Household } \\
\text { genebank, } \\
\text { Community } \\
\text { genebank, } \\
\text { repatriation, } \\
\text { diversity fair, } \\
\text { diversity block, } \\
\text { diversity field } \\
\text { school, school field } \\
\text { genebank, village } \\
\text { level field genebank, } \\
\text { public orchard } \\
\text { management, etc. }\end{array}$ & Across the country & $\begin{array}{l}\text { Training, field visits, seed } \\
\text { supply, packing, storing } \\
\text { and collection supplies, } \\
\text { computer, inviting in } \\
\text { meetings, workshop, } \\
\text { inclusion in different } \\
\text { committee, product } \\
\text { diversification, future } \\
\text { smart food and nutrition } \\
\text { analysis of local } \\
\text { landraces, conservation } \\
\text { village, agrobiodiversity } \\
\text { trail }\end{array}$ \\
\hline
\end{tabular}

\section{On-farm conservation targets}

Successful implementation of on-farm conservation is possible only when farming areas, farmers and crop types are considered and identified appropriately. On-farm conservation is generally targeted to non-commercial areas, especially remotely located farming communities and small holder farmers. Areas where technologies are not easily accessible have relatively become effective for on-farm conservation. Similarly, hot spot areas of agricultural biodiversity are the targets for implementation of on-farm conservation approaches. Field discussion brings out that farmers with poor access to technology and facing biotic and abiotic problems in their crop landraces/varieties are happy to involve directly in on-farm conservation related activities. Agrobiodiversity rich farmers (custodian farmers) are more interested and they are the key players and should therefore be considered ambassador for agrobiodiversity management at local level. Earlier priority was given to cereal and vegetables crops. Some organizations have given due consideration to all kinds of agricultural plant genetic resources including crop wild relatives, wild edible plant and semidomesticated crops. Primarily indigenous crop landraces are targeted through on-farm conservation. Even modern varieties if continuously grown over $4^{\text {th }}$ generation of farmers, are being considered locally well adopted and are considered under conservation modules. 
Journal of Agriculture and Natural Resources (2019) 2(1): 14-35

ISSN: 2661-6270 (Print), ISSN: 2661-6289 (Online)

DOI: https://doi.org/10.3126/janr.v2i1.26012

\section{On-farm conservation approaches}

\section{Hot spot areas for crop specific diversity}

Areas where farmers traditionally grow different landraces of a particular crop at different micro-environments for different purposes e.g. food, nutrition, culture and religious, land type, etc. are treated as hot spot area. Some landraces have very unique traits and have close association with geo-location and farmer needs, and therefore, farmers prefer to grow continuously. Such types of landraces and sites should be identified for on-farm conservation and site may be village, tole or district. In Nepal there are many such sites identified and effectively conservation activities have been implemented. Some examples of hot spot areas are Kachorwa, Bara for rice with 100 landraces; Shivgunj, Jhapa for rice with 90 landraces and for gourds with 45 types; Kunjo, Mustang for wild edible mushroom with 23 types and for bean with 12 different types; Talium, Jumla for bean with 20 landraces; Ghanteshwor, Doti for NTFPs with 57 species; Syanda, Humla for amaranth with 19 landraces of different species; Begnas, Kaski for finger millet with 10 landraces; Ratanchura, Sindhuli for finger millet with 12 landraces and for Junar with 9 types; Rampur, Dang for rice with 36 landraces; Agyauli, Nawalparasi for taro with 9 landraces and for yam with 12 landraces and Purkot, Tanahun for banana with 53 different types.

\section{Household genebank}

Some farmers in particular have traditionally conservation mind i.e. always interested to grow different type of crop species and landraces. They enjoy having large number of diversity and prefer to share diversity among the farmers. Such farmers are therefore called agrobiodiversity rich farmers or custodian farmers. Agrobiodiversity maintained by such farmer is household genebank. Household genebank is the system of conservation and utilization of agrobiodiversity at household level. Under household genebank, there are two types, one is household seed bank and another is household field genebank. Household seed bank deals only orthodox crops and household field genebank deals non-orthodox crops. Generally non-orthodox crops are maintained in kitchen garden as well as home garden. Such farmer is nodal one in the farmers' seed network system. Across the country there are more than 500 such household genebnks and some are listed in Table 4. 
Journal of Agriculture and Natural Resources (2019) 2(1): 14-35

ISSN: 2661-6270 (Print), ISSN: 2661-6289 (Online)

DOI: https://doi.org/10.3126/janr.v2i1.26012

Table 4. List of household genebank (custodian farmers), their address and crops maintained

\begin{tabular}{lllccc}
\hline SN & Custodian farmer & Address & \multicolumn{2}{c}{ Total maintained, n } \\
\cline { 3 - 5 } & & Species & Varieties & Rare \\
\hline 1. & Khem Bahadur Chand & Patharaiya VDC, Kailali & 123 & 116 & 5 \\
2. & Indra Devi Oli & Ghanteshwor-3 VDC, Doti & 31 & 13 & 6 \\
3. & Til Bahadur Rawal & Tallum VDC, Jumla & 55 & 20 & 4 \\
4. & Prem Bishwakarma and Jhuma & Kanchanpur-6, Hariharpur, Bake & 15 & 14 & 8 \\
& Biswhakarma & & & & \\
5. & Phlarani Tharu & Naubasta, Saheluwa Gaun, Banke & 30 & 6 & 3 \\
6. & Kaliram Tharu and Indrani & Beluwa-9, Bardiya & 68 & 60 & 4 \\
& Tharu & & & & \\
7. & Surya Prasad Adhikari and & Dadatha, Begnas-1, Kaski & 64 & 152 & 5 \\
& Saraswati Adhikari & & & & \\
8. & Lal Kumari Thapa and Jaya & Chaur, Lekhnath-11, Kaski & 90 & 124 & 7 \\
& Bahadur Thapa & & & & \\
9. & Shanta Bohora & Chamkipur VDC, Rupandehi & 47 & 14 & 7 \\
10. & Man Bahadur Ghalan & Dalchoki VDC, Lalitpur & 72 & 37 & 4 \\
11. & Som Bahadru Ale Magar & Faparbari-8, Ratamata, Makawanpur & 40 & 45 & 5 \\
12. & Hark Bahadur Syangtan & Parawanipur-2, Sarlahi & 60 & 110 & 4 \\
13. & Anita Khadka Sherpa & Duwagadi-9, Jhapa & 3 & 40 & 1 \\
\hline
\end{tabular}

\section{Community genebank}

Community Seed Bank was established earlier in Nepal for handling orthodox crops e.g. cereals, grain legumes and vegetables. Their seeds are relatively easy for drying, collecting, storing, packing and handling. They are the main crops in most of the communities; therefore, CSBs were established targeting such seeds. About 40\% of total APGRs in Nepal are non-orthodox and needs to give them priority for conservation and use. NAGRC therefore has given emphasis to conserve both orthodox and non-orthodox crops. Later many communities also realized to consider all locally available APGRs in the conservation works. NAGRC has formulated and started working on different approaches for conservation of all types of APGRs. These approaches relate with the types of APGRs based on the conservation modules needed to store them. Conservation of both orthodox and non-orthodox by the community is called Community Genebank which consists of community seed bank and community field genebank. CSB deals only orthodox crops and CFGB handles only nonorthodox crops. Generally CSB and CGB are named with the prefix of location name, e.g. Dalchoki CSB, means Dalchoki is location or village name. To be a CSB or CGB, there should be conservation and utilization works of local crop diversity, only dealing modern varieties are not considered CSB.

For CSB different names are in practices around the globe eg community gene bank, farmer seed house, seed hut, seed wealth center, seed savers group, association, or network, community seed reserve, seed library, and community seed bank (Vernooy et al., 2015). There are many variants of CFGB such as village level FGB, religious site-based FGB, community based crop specific park and community managed orchard, etc. First CFGB was established by Gadharia Community in Kailali district in 2010 by growing 76 local mango landraces in 5.5 ha land. There are more than 8 CFGB in Nepal. Due to the clonal propagation in CFGB, diversity may be narrow; therefore, we also focused on growing such plants through seeds. 
Journal of Agriculture and Natural Resources (2019) 2(1): 14-35

ISSN: 2661-6270 (Print), ISSN: 2661-6289 (Online)

DOI: https://doi.org/10.3126/janr.v2i1.26012

The main target of CSB is to make easy access of local crop diversity to the farmers so the local crop diversity can be conserved through continued growing. Community involves themselves for management of local crop diversity. Within a CGB, there may be many Household Genebanks. Nepal is very unique on using CSBs and CGBs approaches for conservation and sustainable utilization of APGRs. First CSB was established in 1994 in Dalchoki, Lalitpur (Joshi, 2013) and afterwards there are many national events related to CSBs. NARC annually allocates budget for on-farm conservation, therefore, conservation success are relatively good on on-farm conservation in Nepal.

Based on the current status, CSBs in Nepal can be grouped into active CSB, passive (dormant) CSB, collapsed CSB and transmuted (transformed) CSB. Active CSBs are those which are functional and working actively on conservation and utilization of local crop landraces at current time. Passive CSBs are those that were functional in past but due to many reasons, it is not currently dealing any seeds supply system and committee is not holding any meetings and involving in any activities. However, buildings and all materials are in place and one can expect to revive in near future. Collapsed CSBs are no more in existence though earlier they were functional with the working modalities of CSB. Transmuted CSBs are those which were earlier working on local crop diversity but later they completely excluded the local crop diversity and involve in different other activities. In Nepal, there are 40 active CSBs, 6 passive CSBs, 3 collapsed and 95 transformed CSBs. These $144 \mathrm{CSBs}$ are located in 33 districts out of total 77.

The reasons of becoming transmuted, passive and collapsed should be documented so that it can be a guiding document for other CSBs to sustain successfully for longer time. One of the passive CSB said that it become passive because of political conflict. Earthquake is the major reason for collapsing CSB in other area. CSBs have been transmuted because of mainly issues on sustainability. Just conservation work on local crop diversity is not enough to mobilize the farmer group and they faced always financial constraints. Both governmental and non-governmental organizations have been actively involved on establishing CSBs in the country. CDD and NAGRC are the main governmental agencies and LIBIRD and Action Aid are main among non-governmental organizations (Table 5). About 9 organizations are directly involving on establishing and running the CSBs. The highest number of CSBs was established by Oxfam but later they were transmuted. Active CSBs are being established and maintained by LIBIRD. The details of CSB are given in Table 6 .

Table 5. Number of CSB supported by different organizations

\begin{tabular}{lccl}
\hline Organization & Year started & CSB, n & Status \\
\hline USC-Canada Nepal & 1995 & 1 & Active \\
LI-BIRD & 2003 & 21 & Some are passive \\
Parivartan Nepal & 2006 & 1 & Passive \\
Oxfam & 2009 & 90 & Transmuted \\
CDD & 2009 & 9 & Some are collapsed, some are transmuted \\
Action Aid & 2012 & 13 & Active \\
NAGRC & 2003 & 9 & Some are passive \\
SAHAS Nepal & 2013 & 2 & Active \\
FORWARD Nepal & 2016 & 5 & Transmuted \\
\hline
\end{tabular}


Journal of Agriculture and Natural Resources (2019) 2(1): 14-35

ISSN: 2661-6270 (Print), ISSN: 2661-6289 (Online)

DOI: https://doi.org/10.3126/janr.v2i1.26012

Table 6. Some of Community seed banks and community field genebanks and number of crops maintained

\begin{tabular}{|c|c|c|c|}
\hline SN & Community based genebank & Address & $\begin{array}{l}\text { Total crops } \\
\text { conserved, } n\end{array}$ \\
\hline \multicolumn{4}{|c|}{ Community seed bank } \\
\hline 1. & $\begin{array}{l}\text { Kanchan Biodiversity Conservation and } \\
\text { Development Committee }\end{array}$ & $\begin{array}{l}\text { Chandradangi, Shivgunj VDC, } \\
\text { Jhapa }\end{array}$ & $15(131)$ \\
\hline 2. & $\begin{array}{l}\text { Biodiversity Conservation and Development } \\
\text { Committee }\end{array}$ & Agyauli, Nawalparasi & $21(57)$ \\
\hline 3. & $\begin{array}{l}\text { Biodiversity Conservation and Development } \\
\text { Committee }\end{array}$ & Belwa, Bardiya & $16(56)$ \\
\hline 4. & $\begin{array}{l}\text { Biodiversity Conservation and Development } \\
\text { Committee }\end{array}$ & Shankarpur, Kanchanpur & (86) 15 \\
\hline 5. & $\begin{array}{l}\text { Ranibas Organic Agricultural Cooperatives } \\
\text { Limited }\end{array}$ & Ranibas, Sindhuli & $43(143)$ \\
\hline 6. & Bhawani Community Seed Bank & Talium, Jumla & $18(33)$ \\
\hline 7. & Dalchowki Community Seed bank & Dalchoki, Lalitpur & $33(102)$ \\
\hline 8. & Shree Community Seed Bank & Rasuwa & $29(94)$ \\
\hline 9. & $\begin{array}{l}\text { Shree Namisthan Krishi Samrachan Sahakari } \\
\text { Limited tatha biubijan Bank }\end{array}$ & Gamaudi-6, Dailekh & \\
\hline 10. & Sunaulo Community Seed bank & Rampur, Dang & $7(79)$ \\
\hline 11. & Mahadev Seed Bank & Patmara, Jumla & $15(24)$ \\
\hline 12. & $\begin{array}{l}\text { Biodiversity Conservation and Management } \\
\text { Committee }\end{array}$ & Kunjo, Mustang & (23) \\
\hline 13. & Ghanpokhara Community Seed Bank & Ghanpokhara, Lamjung & $15(150)$ \\
\hline 14. & $\begin{array}{l}\text { Agriculture Development and Conservation } \\
\text { Society community seed bank }\end{array}$ & Kachorwa, Bara & $13(133)$ \\
\hline 15. & Gadariya Community seed bank & Gadariya, Kailali & $15(122)$ \\
\hline 16. & Amargadhi Community Seed Bank & Amargadhi, Dadeldhura & $11(60)$ \\
\hline 17. & Khalanga Community Seed Bank & Khalanga, Jajarkot & $3(3)$ \\
\hline 18. & Simichaur Community Seed Bank & Simichaur, Gulmi & $3(3)$ \\
\hline 19. & Rampur Community Seed Bank & Rampur, Okhaldhunga & $3(3)$ \\
\hline 20. & Barchok Community Seed Bank & $\begin{array}{l}\text { Barchok, Thumpakhar, } \\
\text { Sindhupalchok }\end{array}$ & $11(80)$ \\
\hline 21. & Mudhe Community Seed Bank & $\begin{array}{l}\text { Mudhe, Sankhuwasabha, } \\
\text { Tamaphok }\end{array}$ & $12(84)$ \\
\hline 22. & Majhimtar Community Seed Bank & Majhimtar, Jogimara, Dhading & $14(64)$ \\
\hline 23. & Purkot Community Seed Bank & Purkot, Tanahun & $12(53)$ \\
\hline 24. & Gaira Community Seed Bank & Gaira, Ghanteshwor, Doti & $17(31)$ \\
\hline 25. & Tharu Agro-biodiversity conservation group & Simariya, Sunsari & $1(21)$ \\
\hline 26. & Farmer Group Coordination Committee & Pathraiya, Kailali & $8(42)$ \\
\hline 27. & $\begin{array}{l}\text { Ekata Biodiversity Conservation and } \\
\text { Coordination Committee }\end{array}$ & Masuriya, Kailali & $9(28)$ \\
\hline \multicolumn{4}{|c|}{ Community field genebank } \\
\hline 28. & Agyauli CFGB & Agyauli, Nawalparasi & $4(6)$ \\
\hline 29. & Chhatiwan Banana Park & Chhatiwan, Makwanpur & $3(14)$ \\
\hline 30. & Dalchowki CFGB & Dalchoki, Lalitpur & $4(6)$ \\
\hline 31. & Ghadaria CFGB & Gadharia, Kailali & $3(80)$ \\
\hline 32. & Kachorwa CFGB & Kachorwa, Bara & $5(5)$ \\
\hline 33. & Purkot CFGB & Purkot, Tanahu & $4(8)$ \\
\hline 34. & Rainas CFGB & Rainas, Lamjung & $5(10)$ \\
\hline 35 . & Sanosudha CFGB & Sanosudha, Makwanpur & $3(14)$ \\
\hline
\end{tabular}

Figure in parenthesis indicates number of landraces 
Journal of Agriculture and Natural Resources (2019) 2(1): 14-35

ISSN: 2661-6270 (Print), ISSN: 2661-6289 (Online)

DOI: https://doi.org/10.3126/janr.v2i1.26012

\section{Religious site based field genebank}

In Nepal, religious sites are automatically protected and such locations can be considered effective for conservation of cultivated crops in addition to crop wild relatives and wild edible plants. Such sites should be managed by nearby community. There are more than 100 such sites and some species are being protected in such sites. Many communities are interested to involve in such type of conservation method. Such sites are excellent for crop wild relatives, wild edible plants and semi domesticated crop species and landraces. It can be considered as Temple Garden as well e.g. Muktnath Temple Garden, Pashupati Temple Garden, etc.

\section{School field genebank}

Conservation of non-orthodox crops around school compound is called school field genebank. Students are requested to collect plants from their own house and they are grown around school for conservation, study, harvest, and environment protection. Generally all plants available in the command areas are conserved in school field genebank including school garden and farmers, researchers can access these germplasm when they needed. In Nepal there are many schools, college, and campus with many non-use lands. Parivartan Nepal, NAGRC and COPPADES have started establishing school field genebank in 7 schools (Table 7). All databases are being managed by NAGRC and by respective school. School prefers to grow and maintain perennial types of crops because of easy for maintenance. For establishing school field genebank, students should be guided for exploration and survey, sites identification, listing and prioritizing crop species and mapping their center of diversity. They should also learn herbarium preparation and passport data collection. These materials then can be used for characterization and evaluation, regeneration and multiplication, diversity assessment and distribution.

Table 7. School field genebank and major crops and collections

\begin{tabular}{|c|c|c|c|c|}
\hline SN & School & Address & Major crops & Total collections \\
\hline 1 & $\begin{array}{l}\text { Budhanilkantha } \\
\text { School }\end{array}$ & Kathmandu & $\begin{array}{l}\text { Deciduous fruit (peach, pear and } \\
\text { Citrus) including cereal (seed } \\
\text { museum) and sugarcane }\end{array}$ & 25 \\
\hline 2 & Pattharkot School & Sarlahi & Banana and Mango & 16 \\
\hline 3 & $\begin{array}{l}\text { Janata Higher } \\
\text { Secondary School }\end{array}$ & $\begin{array}{l}\text { Phaparbari, } \\
\text { Makawanpur }\end{array}$ & $\begin{array}{l}18 \text { accessions of Mango and 5of } \\
\text { litchi }\end{array}$ & 23 \\
\hline 4 & $\begin{array}{l}\text { Gauri Shankar } \\
\text { Secondary School }\end{array}$ & Ghantehwor, Doti & $\begin{array}{l}\text { Cinnamomum, Emblica and } \\
\text { Sugandhakokila }\end{array}$ & 10 \\
\hline 5 & Alkataar School & Tinpiple, Lamjung & Banana, guava, coffee & 8 \\
\hline 6 & $\begin{array}{l}\text { Paklihawa Krishi } \\
\text { Campus }\end{array}$ & $\begin{array}{l}\text { Paklihawa, } \\
\text { Bhairawa }\end{array}$ & Banana, guava, mango & 25 \\
\hline 7 & $\begin{array}{l}\text { Shree Bhairab Kali } \\
\text { mabi }\end{array}$ & Duipiple, Lamjung & Banana, guava, citrus & 15 \\
\hline
\end{tabular}

\section{Village level field genebank}

In village level FGB, diversity is managed by growing different landraces by each village member and total diversity is conserved at a village level. Community has also established crop specific diversity parks e.g. banana park in Chattiwan, Makawanpur. Both village level FGB and crop specific park were first established by Parivartan Nepal in 2012 in Makawanpur, where different landraces of banana and taro are being managed (Table 8). 
Journal of Agriculture and Natural Resources (2019) 2(1): 14-35

ISSN: 2661-6270 (Print), ISSN: 2661-6289 (Online)

DOI: https://doi.org/10.3126/janr.v2i1.26012

Table 8. List of village level field genebank and crops maintained

\begin{tabular}{lllll}
\hline SN & $\begin{array}{l}\text { Name of village level } \\
\text { field genebank }\end{array}$ & Address & Major crops in & $\begin{array}{c}\text { Diversity } \\
\text { maintained }\end{array}$ \\
\hline 1 & $\begin{array}{l}\text { Jabik Bibidhata Samiti } \\
\text { Ratanchura citrus gene } \\
\text { bank }\end{array}$ & $\begin{array}{l}\text { Purkot, Tanahun } \\
\text { Sindhuli }\end{array}$ & $\begin{array}{l}\text { Banana } \\
\text { Citrus }\end{array}$ & $\begin{array}{l}44 \text { accessions } \\
\text { species }\end{array}$ \\
3 & $\begin{array}{l}\text { Singhnath Krisak } \\
\text { Samuha }\end{array}$ & $\begin{array}{l}\text { Agyouli, } \\
\text { Nawalparasi }\end{array}$ & Yam and Taro & 16 landraces \\
4 & $\begin{array}{l}\text { Jabik Bibidhata Samiti } \\
\text { Chattiwan Krishak } \\
\text { Samuha }\end{array}$ & $\begin{array}{l}\text { Doti } \\
\text { Chattiwan, } \\
\text { Makwanpur }\end{array}$ & $\begin{array}{l}\text { MAPs } \\
\text { Banana and taro }\end{array}$ & 57 species \\
\end{tabular}

\section{Rejuvenation of pubic and community orchards}

More than 100 public mango orchards can be found mainly in Lamjung, Kaski, Gorkha and Tanahu districts (Upadhya et al., 2017). Some of them are listed in Table 9. Most of them are very old and no one is taking care of them. Due to very old age plant, they are almost at the stage of extinction. NAGRC has started working on rejuvenating such orchards since 2016. Rainas Community in Lamjung has managed old mango orchard which was initially public, now it is managed by community (and called community mango park or community field genebank) following the management system of community forest.

\section{Table 9. Name list of public orchards and crop maintained}

\begin{tabular}{|c|c|c|c|c|}
\hline SN & Orchard & Address & Owner & Major crops \\
\hline 1. & $\begin{array}{l}\text { Ghiling Apple } \\
\text { Orchard }\end{array}$ & $\begin{array}{l}\text { Ghiling village, } \\
\text { Mustang }\end{array}$ & $\begin{array}{l}\text { Shree Jana Jyoti Primary } \\
\text { School }\end{array}$ & Apple \\
\hline 2. & $\begin{array}{l}\text { Kalika Mandir } \\
\text { Parisar }\end{array}$ & Baglung Muncipality-1 & Mandir Committee & Mango and Wood Apple \\
\hline 3. & Narayansthan & $\begin{array}{l}\text { Narayansthan-2, } \\
\text { Baglung }\end{array}$ & Mandir Committee & Mango and Black Plum \\
\hline 4. & Ram Janaki Mandir & $\begin{array}{l}\text { Mahendra Adarsh-4, } \\
\text { Bara }\end{array}$ & Temple & Mango and Litchi \\
\hline 5. & Ranibas Mandir & Simraungaud-2, Bara & Temple & Mango and Litchi \\
\hline 6. & Siddeshwor Mandir & Kalaiya- 6 , bara & Temple & Mango and Litchi \\
\hline 7. & Surunga & Kushaha VDC, Saptari & $\begin{array}{l}\text { Surunga Community } \\
\text { Forestry Group }\end{array}$ & Mango \\
\hline 8. & Sukhlahi & $\begin{array}{l}\text { Madhupati-4,5,6, } \\
\text { Saptari }\end{array}$ & $\begin{array}{l}\text { Sukhlahi Community } \\
\text { Forestry Group }\end{array}$ & Mango \\
\hline 9. & Sepa Garden & $\begin{array}{l}\text { Bhanu Municipality, } \\
\text { Tanahu }\end{array}$ & Sepa Village & Mango \\
\hline 10. & $\begin{array}{l}\text { Uppalo Bhotewadar } \\
\text { Garden }\end{array}$ & $\begin{array}{l}\text { Bhotewadar, } \\
\text { Sundarbazar } \\
\text { Municipality, Lamjung }\end{array}$ & Bhotewader Village & Mango \\
\hline 11. & Thati Mango Garden & Bichaur VDC, Lamjung & Thati Bazar & Mango \\
\hline 12. & $\begin{array}{l}\text { Paudi, Sundar bazar, } \\
\text { Mane Chauka }\end{array}$ & $\begin{array}{l}\text { Paudi, Sundar Bazar, } \\
\text { Lamjung }\end{array}$ & Public & Mango \\
\hline 13. & Thati Mango Garden & $\begin{array}{l}\text { Rainaas Municipality-8, } \\
\text { Lamjung }\end{array}$ & Timure Village & Mango \\
\hline 14. & $\begin{array}{l}\text { Bhuwane Mango } \\
\text { Garden }\end{array}$ & Harmi VDC-8, Gorkha & $\begin{array}{l}\text { Pande Village and Miya } \\
\text { Bogati Village }\end{array}$ & Mango \\
\hline 15. & $\begin{array}{l}\text { Katbhote Mango } \\
\text { Garden }\end{array}$ & $\begin{array}{l}\text { Malcha Kharka-3, } \\
\text { Lamjung }\end{array}$ & Sahilitaar Vilage & Mango \\
\hline 16. & Tintpiple Mango & Rainaas Municipality-7, & Tinpiple Village & Mango \\
\hline
\end{tabular}


Journal of Agriculture and Natural Resources (2019) 2(1): 14-35

ISSN: 2661-6270 (Print), ISSN: 2661-6289 (Online)

DOI: https://doi.org/10.3126/janr.v2i1.26012

\begin{tabular}{|c|c|c|c|c|}
\hline SN & Orchard & Address & Owner & Major crops \\
\hline & Garden & Lamjung & & \\
\hline 17. & $\begin{array}{l}\text { Dhamili Kuwa } \\
\text { Mango Orchard }\end{array}$ & $\begin{array}{l}\text { Rainaas Municipality-3, } \\
\text { Lamung }\end{array}$ & Dhamilikuwa Village & Mango \\
\hline 18. & $\begin{array}{l}\text { Garambesi Mango } \\
\text { Orchard }\end{array}$ & $\begin{array}{l}\text { Rainaas Municipality-4, } \\
\text { Lamjung }\end{array}$ & Garambesi Village & Mango \\
\hline 19. & $\begin{array}{l}\text { Bhimsen Mango } \\
\text { Orchard }\end{array}$ & Namjung, Gorkha & Public & Mango \\
\hline 20. & $\begin{array}{l}\text { Lahare Pipal Mango } \\
\text { Orchard }\end{array}$ & $\begin{array}{l}\text { Madhy Nepal } \\
\text { Municipality-9, } \\
\text { Lamjung }\end{array}$ & Purano Hatiya & Mango \\
\hline 21. & Kusunde Orchard & $\begin{array}{l}\text { Alkataar, Rainaas } \\
\text { Municipality-7, } \\
\text { Lamjung }\end{array}$ & Alkataar Village & Mango \\
\hline 22. & Bhorletaar & Bhorletaar, Lamjung & Public & Mango \\
\hline 23. & Parbhas Bagaicha & $\begin{array}{l}\text { Tansen Muncipality-14, } \\
\text { Palpa }\end{array}$ & Public & Mango \\
\hline 24. & Pantar Bagaicha & Hugi-4, Palpa & Public & Mango \\
\hline 25. & $\begin{array}{l}\text { Satmule Suntala } \\
\text { Bagaicha }\end{array}$ & Kughara-7, Parbat & Public & Orange \\
\hline 26. & $\begin{array}{l}\text { Gunte Suntala } \\
\text { Bagaicha }\end{array}$ & Salija-9, Parbat & Public & Orange \\
\hline 27. & $\begin{array}{l}\text { Dhaulapara Suntala } \\
\text { Bagaicha }\end{array}$ & Lekhfat, Parbat & Public & Orange \\
\hline 28. & Lapsi Bagaiha & Shankarpokhari, Parbat & Public & Hog Plum \\
\hline 29. & Brabal & $\begin{array}{l}\text { Syafru-5, Brabal, } \\
\text { Rasuwa }\end{array}$ & Public & $\begin{array}{l}\text { Apple, Peach, Plum and } \\
\text { Walnut }\end{array}$ \\
\hline 30. & Malika & Malika, Dailekh & Public & Mango and Mandarin \\
\hline
\end{tabular}

\section{Landrace enhancement}

Genetic enhancement of landraces is necessary for deploying unutilized germplasm available and creating vast genetic variability for development of productive varieties. National Genebank has given due priority to improve the landraces in collaboration with farmers and communities. The steps used for landrace enhancement is given in Figure 3. Some landraces developed this way has been registered in National Seed Board. Enhanced landraces in collaboration with communities and farmers are Jethobudo Dhan, Gujmuje Rayo, Dude Rayo, Kachorwa-4 Dhan, Dude Chino, Rato Kodo, Paheli Simi, Jumli Simi, Kalo Kaguno, Sunale Latte, Borang Dhan, etc. NAGRC has focused on developing site specific as well as household specific varieties from local landraces.

SHIP Nepal has involved farmer groups, cooperatives and custodian farmers at Humla for conducting participatory varietal selection on Tinmase landrace of maize, Pabe landrace of wheat and local finger millet. Similarly, LI-BIRD through farmers groups has been doing PVS on Tilki rice at Dang, genetic enhancement of Hariyo Kakro (cucumber) in Sindhuli; Kalo Nuniya rice in Jhapa; amaranths in Humla and Jumla. Through this process, Biramphool-3 rice has been developed and it is under the process of registration. Parivartan Nepal has also doing seed selection in Gajale Bodi (cowpea). 
Journal of Agriculture and Natural Resources (2019) 2(1): 14-35

ISSN: 2661-6270 (Print), ISSN: 2661-6289 (Online)

DOI: https://doi.org/10.3126/janr.v2i1.26012

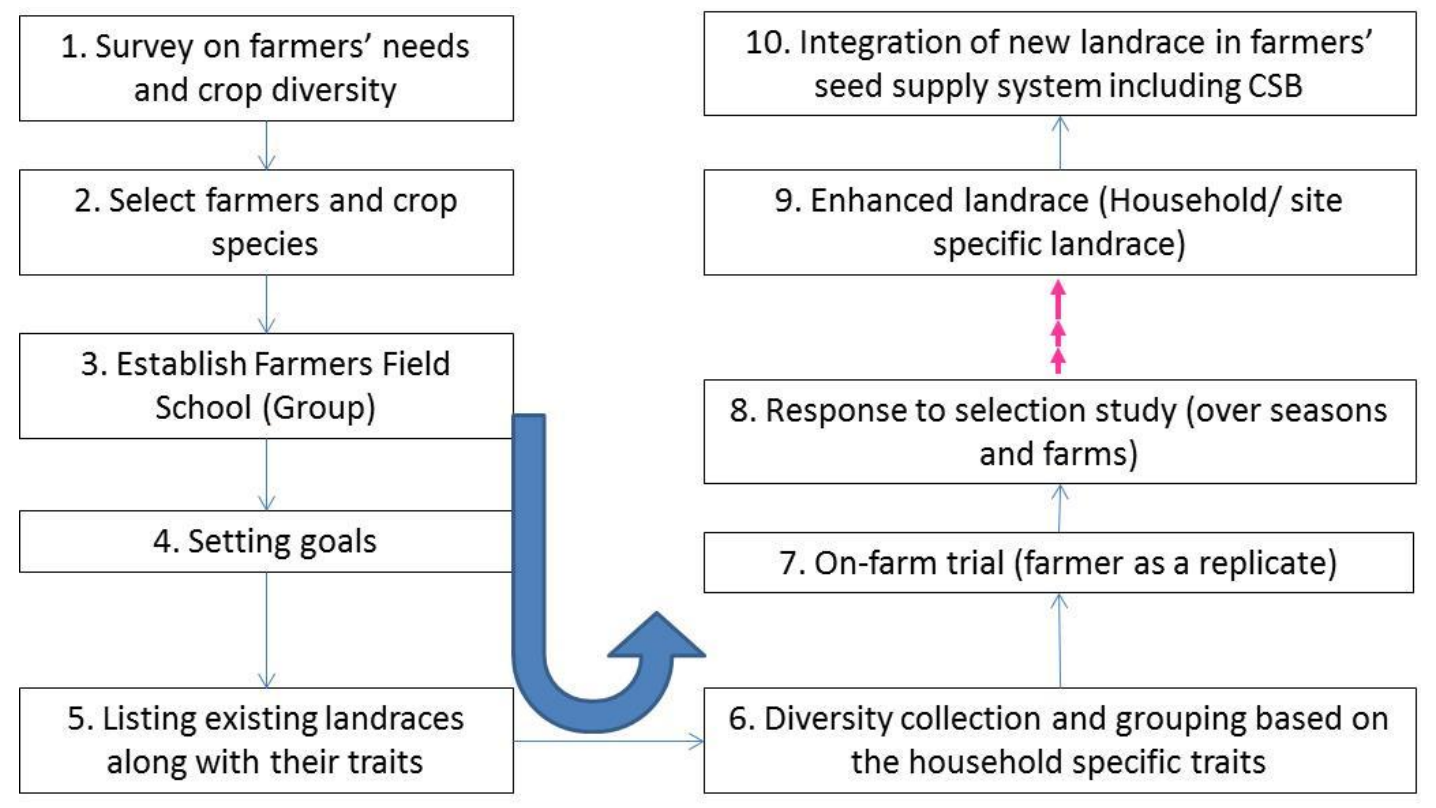

\section{Figure 3. Steps for participatory genetic enhancement of crop landraces (landrace enhancement and conservation, LEC program).}

\section{Recognition of cultural and religious value of landraces}

Farmers still cultivate landraces that have culturally and religiously linked traits: though few in numbers these landraces have adapted to local environmental conditions thereby demonstrating variable adaptation to environmental extremities.

Table 10. Local landraces with their cultural and religious values

\begin{tabular}{|c|c|c|c|c|}
\hline \multirow[t]{2}{*}{$\mathbf{S N}$} & \multirow[t]{2}{*}{ Crop } & \multirow[t]{2}{*}{ Landrace } & \multicolumn{2}{|c|}{ Values/ uses } \\
\hline & & & Cultural & Religious \\
\hline 1. & Sesame & Kalo & Sarad, Garha Shanti & \\
\hline 2. & Rice & Rato tude & & Chat festival \\
\hline 3. & Cucumber & Madale & & Teej, Tihar \\
\hline 4. & Black Gram & Kalo Mas & Nag-pooja-Tamang & Makara Sankranti-Kichhadi \\
\hline 5. & Ricebean & Local & $\begin{array}{l}\text { Batuk and Bara during marital } \\
\text { ceremony, one of the grain } \\
\text { legume of Kwanti }\end{array}$ & Kichhadi in Maghe-Sankranti \\
\hline 6. & Rice & Anandi & & $\begin{array}{l}\text { Chichar at Maghe-Sankranti } \\
\text { Teej: Latte/Chichar }\end{array}$ \\
\hline 7. & Ash Gourd & Begnas local & Garha Shanti & \\
\hline 8. & Barley & Local & Festivals & \\
\hline 9. & Sweet lime & Chaksi & & $\begin{array}{l}\text { Religious value in Newar } \\
\text { community }\end{array}$ \\
\hline 10. & Rice & Sathi & & Chat festival \\
\hline 11. & Sugarcane & Local & & Maha Shivratri \\
\hline 12. & Walnut & Date walnut & & Tihar \\
\hline 13. & Finger millet & Samdhi Kodo & $\begin{array}{l}\text { Acceptable to offer when son-in } \\
\text { law visit father-in law house }\end{array}$ & \\
\hline 14. & Sweet Potato & Local & & $\begin{array}{l}\text { Makara Sankranti and Thula } \\
\text { Ekadashi }\end{array}$ \\
\hline
\end{tabular}


Journal of Agriculture and Natural Resources (2019) 2(1): 14-35

ISSN: 2661-6270 (Print), ISSN: 2661-6289 (Online)

DOI: https://doi.org/10.3126/janr.v2i1.26012

It implies there is low risk of extinction of such landraces and much potential to be conserved and served as repository of gene pool for the development of new varieties that enrich biodiversity and maintain and stabilize ecosystem in a sustainable way to make it functional. Therefore, such landraces have been listed and presented in Table 10 so that knowledge and value of such landraces will transfer to young people, students and among large mass of farmers.

\section{Recognition of crop landraces as geographical indicators}

Due to varied local agro-climatic conditions, there are numerous geographically linked traits in many crop landraces (Joshi et al., 2017b). Because of very specialty and geographical differences, these landraces even today provide food security at the family and village levels but due to the replacement by genetically uniform and high-yielding varieties these landraces are becoming more threatened and suffering from genetic erosion. However, it is believed that owing to having unique and special traits, the conservation of these landraces is easy if its values are further scaled up. Farmers are central participants in the conservation of such landraces thus these landraces have been identified in collaboration with them. We have encouraged and facilitated communities to get GI rights on these products. Among the different unique landraces, some of them are presented in Table 11.

Table 11. Local landraces that are used as geographical indicators

\begin{tabular}{|c|c|c|c|c|}
\hline SN & Crops & Landraces & Location & Indicators, use values \\
\hline 1. & Rice & Pokhreli Jethobudo & Kaski & $\begin{array}{l}\text { Together with natural beauty Pokhara valley is } \\
\text { also known for Jethodbudo rice variety. Aromatic } \\
\text { rice, good in taste, soft and fetching higher price } \\
\text { and demand in market. }\end{array}$ \\
\hline 2. & Rice & Jorayal Basmati & Doti & $\begin{array}{l}\text { Jorayal is a valley of Doti famous for natural } \\
\text { beauty and aromatic rice. Aromatic rice, softness, } \\
\text { fine long grains, very delicious taste, contain more } \\
\text { starch, long straw and preferred by livestock, more } \\
\text { straw production }\end{array}$ \\
\hline 3. & Citrus & Junar & Sindhuli & $\begin{array}{l}\text { Junar is the geographical indicator of Ratanchura } \\
\text { Village Development Committee of Sindhuli }\end{array}$ \\
\hline 4. & Rice & Jumle Marshi & $\begin{array}{l}\text { Jumla, } \\
\text { Humla }\end{array}$ & $\begin{array}{l}\text { Indication of landrace grown in high altitude of } \\
\text { world. }\end{array}$ \\
\hline 5. & Rice & Chomrong & $\begin{array}{l}\text { Chhomron } \\
\text { g, Kaski }\end{array}$ & $\begin{array}{l}\text { Cold tolerant, durable resistant to leaf and neck } \\
\text { blast diseases, field resistant to bacterial sheath } \\
\text { brown rot }\end{array}$ \\
\hline 6. & Chilli & Akbare & Ilam & $\begin{array}{l}\text { Unique and strong pungency, high capasaicin and } \\
\text { very hot. }\end{array}$ \\
\hline 7. & Tea & & $\begin{array}{l}\text { Mai- } \\
\text { Valley, } \\
\text { Ilam }\end{array}$ & Good taste \\
\hline 8. & Rice & Tilki & Dang & $\begin{array}{l}\text { Tilki is famous in DANG. Taste is good, fine rice, } \\
\text { average productivity. Local believe that it is } \\
\text { resistant to shattering, lodging and floods which is } \\
\text { yet to be tested at scientific level. }\end{array}$ \\
\hline 9. & Wheat & Dabdi gohu & Doti & Sweet and drought tolerant \\
\hline 10. & Cucumber & Hariyo Kakro & $\begin{array}{l}\text { Sindhuli, } \\
\text { Dolkha, and } \\
\text { Ramechhap } \\
\text { Pokhara, }\end{array}$ & $\begin{array}{l}\text { Provides satisfactory yield even in the rainy season. } \\
\text { Choice of cosumer and producer because of longer } \\
\text { period green color, softness and taste. } \\
\text { Fine, long grain }\end{array}$ \\
\hline
\end{tabular}


Journal of Agriculture and Natural Resources (2019) 2(1): 14-35

ISSN: 2661-6270 (Print), ISSN: 2661-6289 (Online)

DOI: https://doi.org/10.3126/janr.v2i1.26012

\begin{tabular}{lllll}
\hline SN & Crops & Landraces & Location & Indicators, use values \\
\hline 12. & $\begin{array}{l}\text { Black } \\
\text { Gram }\end{array}$ & Fusro & $\begin{array}{l}\text { Kaski } \\
\text { Keshabtaar } \\
\text { Tanahun }\end{array}$ & Easy cook, sweet tasty, good for masayaura \\
13. & $\begin{array}{l}\text { French } \\
\text { Bean }\end{array}$ & Trishuli Simi & Trishuli & $\begin{array}{l}\text { Tasty and longer shelf life and fibreless at prime } \\
\text { picking period. }\end{array}$ \\
14. & Potato & Mude & $\begin{array}{l}\text { Mude, } \\
\text { Dolakha }\end{array}$ & $\begin{array}{l}\text { Easy cooking and Tasty and high market value and } \\
\text { demand. }\end{array}$ \\
\hline
\end{tabular}

\section{Red zoning and red listing}

All APGRs could not be collected within a certain time period, therefore, National Genebank has guided CSBs for preparing red listing to identify the priority landraces. Red zoning system has been applied for identifying endangered landraces and its details are given by Joshi and Gauchan (2017). Crop diversity should be collected before replacing or losing them from red zone areas. In other than red zone areas, population size and preferential status, and trait distribution criteria have been used to identify vulnerable, rare, endangered and unique landraces. Such systems of classifying crop landraces (red listing) are in practices since 2004 in Nepal (Joshi et al., 2004), however, it is very common in forest genetic resources. In forest genetic resources, IUCN criteria and CITES system are in practices and based on these criteria, many species are red-listed in Nepal. Some of them are APGRs. NAGRC also encourage all CSBs for considering this list to collect and conserve either in their own system or send to National Genebank.

\section{Informal seed supply, participatory seed exchange}

Informal seed supply system in Nepal plays curial role for diversity maintenance at local level. Different organizations have facilitated to promote informal seed system. Nodal farmers in seed network are the target farmers to initiate conservation works. Areas where, modern varieties are not accessible, information seed supply system is the only one that meet seed demands and almost all household involve in this system. Dynamic network structure had key role in provisioning of traditional varieties and maintaining of crop genetic diversity on-farm. Key network members, constituted either as nodal or bridging (connector) farmers, occupy the central position in the network who promote seed flow of local crop diversity, thus strengthening crop genetic resource diversity on-farm (Poudel et al., 2015).

\section{Supporting activities for on-farm conservation}

Farmer and communities always looks for high yielding varieties and conservation is not their priority. Supporting programs therefore are needed to get farmers involved in conservation works. Followings are the programs that help to engage farmers in on-farm conservation.

Linkage: Strong linkage with farmers and farming community is important aspect for successful on-farm conservation. Facilitations are necessary to build linkage among farmers with other relevant stakeholders.

Landrace catalogue: Farmers feel happy to have catalog of their existing landraces. Information on nutrition as well as other cultural practices are very helpful on selection of landraces for farmers and for continue growing. Catalog also helps to increase the adoption 
Journal of Agriculture and Natural Resources (2019) 2(1): 14-35

ISSN: 2661-6270 (Print), ISSN: 2661-6289 (Online)

DOI: https://doi.org/10.3126/janr.v2i1.26012

rate of that particular landraces. Many organizations have developed more than 10 different catalogs of crop landraces.

Awareness and sensitization: This is very important part to get success in on-farm conservation. Different methods have been in practices for sensitization and to aware farming communities on importance of agrobiodiversity and their conservation. Some practices are travel seminar, folk competition, training, exchange visit, diversity essay, diversity song, road drama, food tasting meeting, impact story sharing, etc.

Incentive mechanism: Different kinds of incentives have been providing to farmers and community based on their contribution on agrobiodiversity management. Generally there are incentives for adopting modern varieties in Nepal and this accelerates the replacement of local landraces. Therefore, organization workings on on-farm conservation favored incentive system to farmers and communities. Some incentives are cash prize, field visit, providing seeds free of cost, agricultural tools, training, and membership to different action groups, etc.

Product diversification and favoring local products: Training on products diversification was provided to many communities. Some communities have started business on local products and their different derivatives. Brochures and posters on importance of local products were published and distributed to different stakeholders and demands on such products are rising. Different news media were also used to advertise the local products. Even city dwellers are very much interested on these products and they are willing to pay high price.

Diversity fair and local food fair: Diversity fair is the gathering of farmers with their local crop diversity in certain area and time to show the total diversity in the community and to provide for sharing germplasm each other. Similarly, food fair is the gathering of people along with local products and their diversification, to show the diversity in food. These two fairs greatly helped to promote the conservation activities of local crop diversity. Many organizations at local and national levels regularly organize diversity and food fairs. During fairs, best exhibitors also receive prizes and it encourages farmers to continue the cultivation of diversity.

Diversity blocks: It is crop fields with many blocks growing different landraces of a particular crop. It is generally maintains in farming land where most of the farmers can access. It provides farmers an option to see the total diversity available in the community and select one that they like. It helps to increase the landrace richness in a community and farmers feel happy to get selection opportunity. Many community seed banks and organizations have maintained diversity blocks for a number of crops. National Genebank also provides previous collections to local community for observation in diversity blocks.

Agriculture fair: This is a traditional system of selling local products in seasonal market. Generally this fair is organized once a week and all kinds of agricultural products are displayed for sale. Favorable environments have been created to organize such fair across the country and farmers are very much happy to take part in such fairs. Such fairs also accelerate the seed exchange system and support for growing diversity. 
Journal of Agriculture and Natural Resources (2019) 2(1): 14-35

ISSN: 2661-6270 (Print), ISSN: 2661-6289 (Online)

DOI: https://doi.org/10.3126/janr.v2i1.26012

Registration of local landraces: In Nepal, only registered varieties can be commercially grown. Generally modern varieties are monogenotypic (homozygous) and policy favor to develop such variety. Therefore, with close collaboration with farming communities, more than 10 landraces have been registered. This encourages the farmers to continue the landraces and commercialize it.

Diversity kits: It is the pack of seeds of different crop varieties and landraces for giving to farmers during meeting, field visit and collection. We provide diversity kit free of kit that support to maintain the diversity. Farmers show keen interest on maintaining diversity after getting such kits. More than 5000 kits are annually distributed across the country.

Diversity field school: Farmer field school is very success in Nepal to empower the farmers and to train them. In the same principle of farmer field school, NARC and LI-BIRD has developed diversity field school, where, use and importance of diversity are discussed among farmers visiting different crop fields. Running diversity field school has encouraged and motivated farmers on growing diversity in their fields.

\section{CONCLUSION}

Three strategies, i.e. breeding, in-situ and on-farm are necessary to conserve crop diversity at local level. On-farm conservation is very effective in Nepal and it has contributed to manage about $30 \%$ of total local diversity in Nepal. Among 24 different methods of on-farm conservation, community seed bank and landrace enhancement are widely and effectively used. School field genebank is very easy and low cost technology to conserve large diversity in a single site. Farmers have experiences of low risk due to abiotic and biotic stresses from creating and maintaining maximum diversity within a plot. Valuing the local products and supporting different activities are necessary to encourage farmers for continuing the local crop diversity.

\section{ACKNOWLEDGEMENTS}

Some information was collected from Indra Poudel, LI-BIRD; Chandra Gurung, LI-BIRD; Laxman Shrestha, Parivartan Nepal; Ratna Chandra Upadhya and Subash Gautam. Nepal Agricultural Research Council has provided fund for on-farm conservation.

\section{Authors contributions}

BK Joshi wrote the whole paper and D Upadhya collected some information from fields and extracted information from literatures.

\section{Conflict of interest}

The authors declare no conflicts of interest regarding publication of this manuscript.

\section{REFERENCES}

Altieri, M.A. (1999). The ecological role of biodiversity in agroecosystems. Agriculture Ecosystems and Environment, 74, 19-31.

Jarvis, D.I., Padoch, C., \& Cooper, H.D. (2007). Biodiversity, agriculture and ecosystem services. In D.I. Jarvis, C. Padoch \& D. Cooper (Eds.), Managing Biodivesity in Agricultural Ecosystems (pp.1-12). Columbia University, New York, USA. 
Journal of Agriculture and Natural Resources (2019) 2(1): 14-35

ISSN: 2661-6270 (Print), ISSN: 2661-6289 (Online)

DOI: https://doi.org/10.3126/janr.v2i1.26012

Joshi, B.K., \& Gauchan, D. (2017). Germplasm Rescue: Why and How? In B.K. Joshi \& D. Gauchan (Eds.), Rebuilding Local Seed System of Native Crops in Earthquake Affected Areas of Nepal (pp.41-50). Proceedings of a National Sharingshop, 18 Dec 2017, Kathmandu; NAGRC, Bioversity International and Crop Trust; Kathmandu, Nepal;. https://www.bioversityinternational.org/elibrary/publications/detail/rebuilding-local-seed-system-of-native-crops-inearthquake-affected-areas-of-nepal/

Joshi, B.K., Acharya, A.K., Gauchan, D., \& Bhatta, M.R. (2017a). Agrobiodiversity status and conservation options and methods. In B.K. Joshi, H.B. KC \& A.K. Acharya (Eds.), Conservation and Utilization of Agricultural Plant Genetic Resources in Nepal (pp. 21-38). Proceedings of $2^{\text {nd }}$ National Workshop, 22-23 May 2017, Dhulikhel; NAGRC, FDD, DoA and MoAD; Kathmandu, Nepal.

Joshi, B.K., Singh, D., Chaudhary, P., Ghimire, K.H., \& Khanal, M. (2017b). Biotechnology, geographical information system and climate analog tool for management of APGRs. In B.K. Joshi, H.B. KC \& A.K. Acharya (Eds.), Conservation and Utilization of Agricultural Plant Genetic Resources in Nepal (pp.156-169). Proceedings of $2^{\text {nd }}$ National Workshop, 22-23 May 2017, Dhulikhel; NAGRC, FDD, DoA and MoAD; Kathmandu, Nepal.

Joshi, B.K., Upadhyay, M.P., Gauchan, D., Sthapit, B.R., \& Joshi, K.D. (2004). Red listing of agricultural crop species, varieties and landraces. Nepal Agric. Res. J., 5, 73-80.

Joshi, B.K. (2013). A brief overview of community seed bank initiatives in Nepal. In P. Shrestha, R. Vernooy \& P. Chaudhary, (Eds.), Community Seed Banks in Nepal: Past, Present, Future (pp.41-46). Proceedings of a National Workshop, LIBIRD/USC Canada Asia/Oxfam/The Development Fund/IFAD/Bioversity International, 14-15 June 2012, Pokhara, Nepal.

Joshi, B.K. (2017). Conservation and utilization of agro-biodiversity advanced from 1937 to 2017 in Nepal. In F. Devkota (Ed.), Krishi Sanchar Smarika (pp.181-208). Agricultural Information and Communication Center (AICC), MoAD.

Mijatovic, D., Van Oudenhoven, F., Eyzaguirre, P., \& Hodgkin, T. (2013). The role of agricultural biodiversity in strengthening resilience to climate change: Towards an analytical framework. International Journal of Agricultural Sustainability, 11, 95107.

Poudel, D., Sthapit, B., \& Shrestha, P. (2015). An Analysis of Social Seed Network and Its Contribution to On-Farm Conservation of Crop Genetic Diversity in Nepal. International Journal of Biodiversity (ID 312621), http://dx.doi.org/10.1155/2015/312621

Shrestha, J., Subedi, S., Devkota, H., Acharya, B., Subedi, M., \& Pokhrel, D. (2019). Ecosystem diversity of field crops, garden crops and aquatic plants in Nepal. Working Groups of Agricultural Plant Genetic Resources (APGRs) in Nepal (BK Joshi and R Shrestha, eds). Proc. National Workshop, 21-22 June 2018, Kathmandu. NAGRC, Nepal. Pp.121-130.

Upadhya, D., Joshi, B.K., Dhakal, R., Manandhar, R., Acharya, A.K., \& Sharma, A. (2017). Community and public orchards, and community and school field genebanks in Nepal. In B.K. Joshi, H.B. KC \& A.K. Acharya (Eds.), Conservation and Utilization of Agricultural Plant Genetic Resources in Nepal (pp.102-114). Proceedings of 2nd 
Journal of Agriculture and Natural Resources (2019) 2(1): 14-35

ISSN: 2661-6270 (Print), ISSN: 2661-6289 (Online)

DOI: https://doi.org/10.3126/janr.v2i1.26012

National Workshop, 22-23 May 2017, Dhulikhel; NAGRC, FDD, DoA and MoAD; Kathmandu, Nepal.

Upadhya, D., Dhakal, R., Khadka, K. Rana, S., Acharya, P., Rana, R., \& Chaudhary, P. (2016). Local knowledge on climate-inducted traits in rice for improving crop yield, food security and climate resilience. International Journal of Agriculture Innovations and Research, 5, 385-396.

Vanek, S.J., \& Drinkwater, L.E. (2013). Environmental, social, and management drivers of soil nutrient mass balances in an extensive Andean cropping system. Ecosystems, 16, $1517-1535$.

Vernooy, R., Shrestha, P., \& Sthapit, B. (2015). The rich but little known chronicles of community seed banks. In R. Vernooy, P. Shrestha \& B. Sthapit (Eds.), Community Seed Banks: Origins, Evolution and Prospects (pp.1-8). Bioversity Inernational, Rome. 